\title{
EVALUASI PROGRAM PENDAMPINGAN GURU SD DALAM IMPLEMENTASI KURIKULUM 2013
}

\author{
Widyasari \\ Pendidikan Guru Sekolah Dasar (PGSD) Universitas Djuanda Bogor \\ Jl. Tol Ciawi No. 1, Jawa Barat \\ Email: sari_widya@yahoo.com \\ Muhammad Yaumi \\ Fakultas Tarbiyah dan Keguruan UIN Alauddin Makassar \\ Kampus II: Jalan Sultan Alauddin Nomor 36 Samata-Gowa \\ Email: muhammadyaumi@yahoo.com
}

\begin{abstract}
Abstrak:
Tujuan Penelitian ini adalah untuk mengevaluasi program pendampingan kurikulum 2013 pada tahap perencanaan dan pelaksanaan pendampingan. Penelitian dilakukan di Gugus III Kecamatan Jatiasih Bekasi. Jenis penelitian adalah penelitian evaluasi dengan menggunakan metode penggabungan (mixed method) untuk menganalisis data. Sumber data terdiri atas Ketua Gugus, Instruktur Nasional Kurikulum 2013, dan guru model. Instrumen penelitian adalah pedoman wawancara, lembar observasi, angket, dan studi dokumentasi. Teknik analisis data kualitatif mencakup reduksi data; penyajian data; dan verifikasi data. Data kuantitatif dianalisis dengan menghitung persentase berdasarkan kriteria tidak baik, kurang baik, cukup baik, baik, dan sangat baik. Hasil penelitian menunjukkan bahwa perencanaan program pendampingan dilakukan melalui enam langkah mendesain tujuan, mengidentifikasi potensi, menfasilitasi orientasi bersama, mencocokkan, mempersiapkan peralatan, implementasi pendampingan, dan mengevaluasi dan revisi. Terdapat kendala yang dihadapi guru dalam mengimplementasikan kurikulum 2013, yaitu pendekatan saintifik, membuat soal ulangan harian, rekapitulasi nilai ke dalam rapot. Implementasi pendampingan dalam pelaksanakan $\mathrm{K}$ 2013 mengarah pada pembiasaan untuk mengembangkan aspek kognisi, afeksi, dan psikomotor. Pandangan guru tentang pelaksanaan pendampingan K 13 berada pada kategori baik.
\end{abstract}

\begin{abstract}
:
The purpose of this study was to evaluate mentoring program of 2013 curriculum that focused on planning and implementation phases. The study was conducted in Cluster III Jatiasih District of Bekasi. The type of research was evaluation study by mixed method to analyze the data. The data source consisted of the chairman of the cluster, national instructor of 2013 curriculum, and the model teachers. The research instruments were interview guide, observation sheets, questionnaires, and documentation tools. The techniques of qualitative data analysis include data reduction displays, conclusion drawing and verification. Quantitative data were analyzed by calculating the percentage based on the criteria "not good, poorly good, fairly good, good, and excellent. The results showed that the mentoring program planning is done through a six steps; designing objectives, identifying potential, facilitating orientation, matching, preparing equipment, implementation, evaluation and revision. There were constraints faced by teachers in implementing the 2013 curriculum, namely scientific approach, making daily quiz, score recapitulation and report card. Implementation of 2013 curriculum mento-
\end{abstract}


ring leads to cognitive, affective, and psychomotor aspects. The teachers' opinion on the mentoring program of 2013 curriculum was in the good category.

\section{Kata kunci:}

Evaluasi program, mentoring, implementasi kurikulum

SEJAK diberlakukannya kurikulum baru pada pertengahan tahun 2013 yang lalu maka banyak hal yang perlu dilakukan agar kebijakan pemerintah terkait dengan perubahan kurikulum ini dapat terlaksana dengan baik. Salah satu yang menjadi pertimbangan agar Kurikulum 2013 dapat diterima dan diimplementasikan, maka perlu mempertimbangan faktor-faktor keberhasilannya. Faktor keberhasilan implementasi Kurikulum terbagi menjadi dua kategori, yaitu pertama faktor penentu (buku sebagai bahan ajar, tenaga pendidik dan kependidikan yang memiliki kompetensi), kedua faktor pendukung (penguatan peran pemerintah dalam pembinaan dan pemantauan, serta penguatan manajemen dan budaya sekolah). Baik faktor penentu maupun faktor pendukung, keduanya saling terkait dan melengkapi agar tujuan pendidikan dapat tercapai.

Langkah awal yang telah dilakukan dalam Implementasi Kurikulum 2013 adalah melakukan Pendidikan dan Pelatihan (Diklat) yang diperuntukan bagi guru, Kepala Sekolah dan Pengawas Sekolah. Ketiga komponen ini sangat berperan dalam keberhasilan Implementasi Kurikulum 2013 di lapangan. Oleh karena itu untuk memelihara dan meningkatkan kesinambungan pemahaman dan implementasi Kurikulum 2013 pada masing-masing satuan pendidikan, diprogramkan kegiatan pendampingan untuk para guru dan kepala sekolah. Program pendampingan ini dianggap perlu dilakukan, karena walaupun guru telah dilatih kurikulum 2013 selama lima hari berturut-turut akan tetapi daya serapnya masih di bawah rata-rata. Hal ini dapat dipahami karena sebagian besar guru belum memaknai alasan perubahan kurikulum dengan baik, sehingga mindset atau pola pikir mereka masih belum berubah. Hal ini tentu saja akan memengaruhi penerimaan dan pemahaman guru terkait kurikulum 2013 selanjutnya, di sinilah peran penting program pendampingan. Program pendampingan ini dilakukan sebagai penguatan dalam memahami konsep Kurikulum 2013 berikut perubahannya di lapangan serta untuk membantu mengatasi berbagai kendala yang akan muncul pada saat implementasi kurikulum berlangsung. Untuk memperoleh strategi pendampingan kurikulum 2013 secara tepat, maka terlebih dahulu perlu melakukan evaluasi program pendampingan. Berdasarkan latar belakang yang telah diuraikan di atas maka rumusan masalah dalam penelitian ini adalah Bagaimana Evaluasi Program Pendampingan Guru SD dalam Implementasi Kurikulum 2013? Hasil penelitian ini diharapkan dapat memberi kontribusi bagi pihak penyelenggara program pendampingan implementasi kurikulum 2013 dalam merancang dan melaksanakan proses pendampingan yang efektif, efisien dan menarik.

\section{KAJIAN TEORETIK}

Kegiatan evaluasi merupakan hal yang harus dilakukan dalam suatu sistem pendidikan. Dapat dikatakan bahwa evaluasi merupakan bagian integral dalam suatu 
kegiatan pembelajaran. Menurut Dimyati dan mujiono, evaluasi mencakup hasil belajar yang menekankan pada informasi tentang perolehan peserta didik dalam mencapai tujuan pembelajaran yang telah ditetapkan dan evaluasi pembelajaran merupakan proses sistematis untuk memperoleh informasi tentang keefektifan proses pembelajaran dalam membantu peserta didik mencapai tujuan pembelajaran secara optimal. ${ }^{1}$ Dalam kaitannya dengan evaluasi program, evaluasi dipandang sebagai identifikasi, klarifikasi, dan penerapan kriteria yang dapat dipertahankan untuk menentukan nilai objek evaluasi (kelayakan atau kepantasan) dalam kaitannya dengan kriteria tersebut. ${ }^{2}$ Sedangkan program dipandang sebagai serangkaian kegiatan yang direncanakan yang diarahkan pada menghadirkan perubahan khusus dalam suatu audiens yang dapat diidentifikasi. ${ }^{3}$

Definisi evaluasi dan program yang diberikan di atas dipandang secara terpisah satu sama lain dan perlu dipadukan dalam satu kesatuan yang utuh untuk mendapatkan gambaran komprehensif. Evaluasi program adalah individual systematic studies conducted periodically or on an ad hoc basis to assess how well a program is working. ${ }^{4}$ Artinya, kajian sistematik individu yang dilakukan secara periodik atau atas sesuai dengan target yang diinginkan untuk menilai bagaimana program itu berjalan. Stufflebeam dan Shinkfield membedakan antara teori umum dan khusus tentang evaluasi program. Teori umum tentang evaluasi program mencakup berbagai aspek termasuk karakteristik model, proses dan logik dari percakapan evaluatif, serta menggambarkan bagaimana evaluasi program dinilai dan dijustifikasi. Teori khusus (spesifik) dibatasi pada area, substantif, lokasi, atau periode waktu. ${ }^{5}$

Beberapa penelitian tentang evaluasi program telah banyak dilakukan dan temuan-temuan baru juga banyak digunakan. Greig dkk., mengkaji tentang "Program evaluation of a model to integrate internationally educated health professionals into clinical practice"dan menemukan bahwa mahasiswa internasional yang berpartisipasi dalam program ini memiliki tingkat lulus yang terbaik pada ujian kompetensi Fisioterapi nasional; partisipasi dalam program ini mengakibatkan mereka memiliki 28\% (95\% CI, $2 \%$ sampai $59 \%$ ) kemungkinan lebih kuat pada bagian tertulis daripada rekan-rekan mereka yang tidak mengikuti program. Pada tahun 2010, 81\% dari semua calon IEP yang menyelesaikan program UBC lulus komponen tertulis, dan $82 \%$ lulus komponen klinis. ${ }^{6}$ Penelitian lain juga dilakukan oleh Valerie Ruhe and J. Donald Boudreau yang meneliti tentang "The 2011 Program Evaluation Standards: a framework for quality in medical education programme evaluations" Temuan penelitian menunjukkan standar evaluasi program dapat menerangi ketegangan, dilema dan bahaya yang melekat dalam semua tahap studi evaluasi program dan menawarkan strategi yang dapat membantu untuk merancang dan melakukan studi evaluasi kualitas tinggi. ${ }^{7}$

Selain itu, evaluasi program yang relevan dengan program pendampingan dilakukan oleh Jennifer Browne yang meneliti tentang "A qualitative evaluation of a mentoring program for Aboriginal health workers and allied health professionals". Hasil temuan menunjukkan bahwa sebanyak 18 pendampingan kemitraan yang dibentuk di seluruh Victoria. Data mengungkapkan tiga tema utama dalam kaitannya dengan evalu- 
asi program: (1) program pendampingan memfasilitasi dua arah pembelajaran, (2) tenaga Kesehatan Aborigin dan peserta profesional kesehatan non-Aborigin dilaporkan mampu memenuhi kebutuhan belajar yang telah diidentifikasi melalui kemitraan, (3) kapasitas untuk meningkatkan praktik difasilitasi melalui kesiapan untuk belajar dan praktik mengubah dan atribut pribadi peserta, serta dukungan organisasi dan manajemen. ${ }^{8}$

Istilah pendampingan sering dirujuk dari bahasa Inggris mentoring dan coaching walaupun mempunyai makna yang sedikit berbeda. Pada dasarnya, mentoring dan coaching merupakan aktivitas belajar dan pengembangan yang membagi akar yang sama sekalipun masih menyisahkan perdebatan yang tajam bagi para akademisi dan praktisi karena menyangkut makna dan implikasi dari masing-masing kata tersebut. Kedua kata ini digunakan ketika tingkat kinerja dan motivasi perlu diperbaiki. Oleh karena itu, dikatakan bahwa seorang yang menjadi mentor yang baik juga menjadi coach yang hebat, sebaliknya coach yang hebat adalah mentor yang baik. ${ }^{9}$ Dikatakan pula bahwa "coaching and mentoring are learning relationships which help people to take charge of their own development, to release their potential and to achieve results which they value." 10 Artinya, coaching dan mentoring adalah keterhubungan belajar yang membantu orang untuk bertanggung jawab atas pengembangan yang dilakukan, melepaskan potensi untuk mencapai hasil yang bernilai.

Coaching dan mentoring memang konsep yang berpijak pada tujuan yang sama dan untuk mencapai hasil yang sama pula. Namun, pada hakekatnya kedua istilah tersebut memiliki definisi yang sedikit berbeda satu sama lain, seperti definisi sebagai berikut:

Coaching is a process that enables learning and development to occur and thus performance to improve. To be a successful a Coach requires a knowledge and understanding of process as well as the variety of styles, skills and techniques that are appropriate to the context in which the coaching takes place. ${ }^{11}$

off-line help by one person to another in making significant transitions in knowledge, work or thinking. ${ }^{12}$

Dari definisi tersebut dapat dipahami bahwa yang dimaksud dengan coaching adalah suatu proses yang mendukung terjadinya belajar dan pengembangan dan kemudian memperbaiki kinerja. Untuk mencapai keberhasilan seorang coach membutuhkan pengetahuan dan pemahaman tentang proses dan berbagai gaya, keterampilan, dan teknik yang sesuai dengan konteks di mana terjadinya pelaksanaan coaching. Sedangkan, mentoring adalah bantuan atau bimbingan yang diberikan untuk orang perorang dalam menciptakan transisi pengetahuan, berpikir atau bekerja yang berguna. Mentoring juga dipandang sebagai:

\begin{abstract}
Mentoring is time-proven strategies that can help young people of all circumstances achieve their potential. Mentors are caring individuals who, along with parents or guardians, provide young people with support, counsel, friendship, reinforcement and a constructive example. ${ }^{13}$
\end{abstract}

Mentoring, di sini dipahami sebagai strategi yang dibuktikan dengan waktu (time-proven strategies) yang dapat membantu generasi muda dengan memanfaatkan seluruh keadaan untuk mencapai potensi yang mereka miliki. Mentor adalah individu yang peduli, bersama dengan orang tua atau wali, menyediakan orang-orang muda 
dengan memberikan dukungan, nasihat, penguatan persahabatan, dan contoh yang konstruktif.

Kata parents or guardians dalam definisi tersebut seolah-olah menyiratkan bahwa pelaksanaan pendampingan itu dilakukan oleh orang-orang yang umurnya lebih tua (orang tua) kepada orang yang lebih muda (anak-anak), terkesan bahwa kegiatan pendampingan berhubungan dengan umur. National Mentoring Parnership cenderung memandang bahwa kegiatan pendampingan berhubungan langsung dengan umur, paling tidak dilakukan oleh senior kepada yuniornya. Namun, jika merujuk pada konsep the skill-will matrix ${ }^{14}$ di mana proses pendampingan hanya dilihat dari keterampilan (skill) dan kemauan (will) untuk menyelesaikan tugas, maka umur bukanlah menjadi ukuran dalam pelaksanaan kegiatan pendampingan.

Salah satu alasan mengapa kegiatan pendampingan perlu dilakukan dalam konteks pendidikan adalah membantu menjembatani perbedaan atau gap antara teori dan praktik. Danim berpendapat bahwa salah satu cara yang dapat dipakai untuk menyukseskan suatu program pembelajaran di sekolah adalah perlu adanya partisipasi guru dalam proses perencanaan, partisipasi dalam kelompok, dan memperkuat persepsi mereka mengenai manfaat program. ${ }^{15}$

Parsloe mendefinisikan Coaching sebagai "a process that enables learning and development to occur and thus performance to improve. ${ }^{16}$ Selanjutnya Parsloe menjelaskan untuk menjadi seorang coach yang berhasil harus memiliki pengetahuan dan pemahaman mengenai proses coaching dengan beragam cara, keahlian dan teknik yang sesuai dengan konteks atau kondisi dimana kegiatan tersebut berlangsung. Sementara mentoring didefinisikan sebagai "a process which support learning and developmen.17

Dalam konteks pelatihan guru, dengan adanya pendampingan diharapkan dapat membantu dan mendorong mereka untuk menciptakan pemahaman baru terkait dengan bagaimana cara mereka mengajar, membantu mereka untuk memperoleh ideide baru, serta untuk memahami apa yang mereka butuhkan agar dapat meningkatkan aspek-aspek lain dari cara mereka mengajar. ${ }^{18}$

\section{METODE PENELITIAN}

Metode yang digunakan dalam penelitian ini adalah penelitian evaluasi dengan menggabungkan dua pendekatan, yakni pendekatan kualitatif dan kuantitatif dalam menganalisis data. Menurut Nana S. Sukmadinata, pendekatan kualitatif dalam bidang pendidikan dan kurikulum pengajaran merupakan hal yang cukup penting, mendeskripsikan fenomena-fenomena kegiatan pendidikan, pembelajaran, implementasi kurikulum pada berbagai jenis, jenjang dan satuan pendidikan. ${ }^{19}$ Pendekatan deskriptif bertujuan untuk mendeskripsikan atau menggambarkan secara sistematis, faktual, dan kontekstual baik yang bersifat alamiah maupun yang dirancang terkait dengan evaluasi proses pendampingan Kurikulum 2013 yang mencakup tahap perencanaan dan pelaksanaan pendampingan. Metode deskriptif kualitatif dalam penelitian ini bertujuan untuk mendeskripsikan fenomena-fenomena apa adanya dari partisipan yaitu Ketua Gugus, Instruktur Nasional, dan guru-guru model dengan mempertimbangkan karakteristik, kualitas, keterkaitan antarkegiatan pendampingan kuri- 
kulum 2013. Pendekatan kuantitatif adalah suatu cara menganalisis data dengan mendeskripsikan nilai, skor, atau data yang dikumpulkan melalui angket berdasarkan kriteria tidak baik, kurang baik, cukup baik, baik, dan sangat baik.

Perangkat instrumen yang digunakan terdiri atas: (1) Wawancara; (2) Observasi; (3) Angket; dan (4) Studi Dokumentasi. Sementara untuk memperoleh data penelitian yang komprehensif dan mendalam maka dilakukan beberapa hal sebagai berikut: (1) Wawancara dalam penelitian ini dilakukan untuk memperoleh data atau keterangan terkait dengan perencanaan dan proses pendampingan dari Ketua Gugus III dan Instruktur Nasional; (2) Observasi, teknik observasi yang dilakukan oleh peneliti adalah untuk mengamati kesesuaian perencanaan pendampingan dengan proses implementasinya; (3) Angket, penyebaran angket dilakukan setelah kegiatan pendampingan selesai. Tujuannya adalah untuk memperoleh data mengenai tingkat pemahaman guru tentang implementasi Kurikulum 2013; dan yang terakhir adalah (4) Studi Dokumentasi, dilakukan untuk mengumpulkan data berupa dokumen atau bahan tertulis pada saat perencanaan hingga tahap proses pendampingan. Teknik analisis data dalam penelitian kualitatif dilakukan dalam tiga tahapan, yaitu: (1) Reduksi Data; (2) Display Data; dan (3) Verifikasi Data dan pengambilan kesimpulan.

\section{HASIL PENELITIAN}

Penelitian ini untuk mengevaluasi proses pendampingan implementasi kurikulum 2013. Temuan-temuan yang diperoleh dalam penelitian ini dikelompokkan menjadi dua bagian. Bagian pertama terkait dengan tahap perencanaan program pendampingan dan bagian kedua terkait dengan proses atau pelaksanaan program pendampingan tersebut.

\section{Tahap Perencanaan Program Pendampingan}

Tahap perencaan ini berlangsung selama 2 (dua) minggu, mulai dari mempersiapkan jadwal, menentukan Instruktur Nasional yang ditugaskan, menyesuaikan dengan jadwal kegiatan di sekolah dan Gugus, serta mempersiapkan tempat pelaksanaan pendampingan yang rencananya akan dilakukan di beberapa sekolah secara bergantian. Hal inipun perlu koordinasi yang baik, karena tidak semua kepala sekolah menyetujui jika guru harus sering meninggalkan sekolah untuk kegiatan pendampingan ditambah jika sekolah tertentu yang ditunjuk untuk melakukan kegiatan pendampingan, tentu hal ini akan berdampak pada peserta didik yang harus dipulangkan lebih awal karena kelasnya akan dipakai. Akan tetapi hal tersebut dapat diatasi dengan membuat jadwal pendampingan siang hari jam 13.00 di mana peserta didik sudah pulang dan guru tidak harus meninggalkan kelas terlalu sering. Ketua Gugus menegaskan bahwa kegiatan pendampingan ini akan memberikan dampak positif pada penguatan guru dalam melaksanakan tugasnya mengimplementasikan Kurikulum 2013 di sekolah masing-masing. Pengumpulan data pada tahap perencanaan diperoleh melalui kegiatan wawancara. 


\section{Wawancara}

Berdasarkan hasil wawancara dengan Ketua Gugus III Jatiasih diperoleh informasi bahwa perencanaan program pendampingan disusun dengan mempertimbangkan masukan dari pengawas, kepala sekolah dan Instruktur Nasional Kurikulum 2013, nantinya baik pengawas maupun Instruktur Nasional akan terlibat langsung dalam proses pendampingan. Setelah materi telah tersusun, langkah selanjutnya adalah membuat jadwal pendampingan. Kegiatan pendampingan akan dilakukan selama enam kali pertemuan ditambah satu kali pertemuan untuk melakukan sosialisasi program pendampingan. Agar peneliti dapat memperoleh gambaran yang utuh terkait dengan perencanaan program pendampingan ini, wawancara juga dilakukan kepada Instruktur Nasional yang tidak lain adalah guru yang sedang mengimplementasikan kurikulum 2013. Berdasarkan hasil wawancara ini diperoleh beberapa gambaran terkait dengan kendala yang dihadapi guru dalam mengimplementasikan kurikulum 2013. Kendala yang dimaksud antara lain adalah sebagian guru masih belum memahami dengan baik proses pembelajaran yang menggunakan pendekatan saintifik, membuat soal ulangan harian, rekapitulasi nilai ke dalam rapot dan beberapa kendala lainnya.

Hasil analisis data dari keseluruhan data yang dikumpulkan melalui wawancara menunjukkan bahwa perencanaan program pendampingan mencakup (1) mendesain dan merencanakan tujuan program pendampingan; (2) mengidentifikasi potensi guru yang didampingi dan pendampingnya; (3) menfasilitasi orientasi bersama (guru yang diberi pendampingan, pendamping (mentor), dan pengawas); (4) mencocokkan antara pendamping dengan yang didampingi; (5) mempersiapkan peralatan untuk pendampingan; (6) implementasi pendampingan; (7) mengevaluasi kemajuan dan mendesain kembali. Ketuju tahapan in dapat digambarkan seperti di bawah ini.

Gambar 1. Perencanaan Program Evaluasi Pendampingan

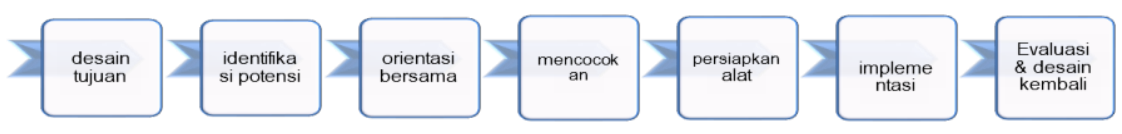

Pertama, mendesain dan merencanakan tujuan program pendampingan mencakup bagaimana kegiatan pendampingan dapat memenuhi visi, misi, dan tujuan satuan pendidikan, dukungan atasan seperti halnya dinas pendidikan kota dapat dicapai, kecocokan antara pendamping (mentor) dengan yang didampingi (guru), ketercapaian harapan bersama antara pendamping, guru, dan satuan pendidikan, jenis pengalaman belajar yang disajikan kepada guru baik pada saat melaksanakan pendampingan maupun setelah selesai guru melaksanakan pembelajaran, dan bentuk evaluasi dan model perbaikan dari keseluruhan komponen kegiatan pendampingan agar mendapat perbaikan yang berarti. Kedua, mengidentifikasi potensi pendamping dan yang didampingi mencakup menyeleksi dan merekrut tenaga secara hati-hati, walaupun pendamping langsung dikirim atau diberikan dari dinas pendidikan, tetapi minimal dilaksanakan di dalam kelas guru-guru yang sangat membutuhkan pendampingan. 
Ketiga, menfasilitasi orientasi bersama antara mentor, pengawas, dan kepala sekolah menjadi pertimbangan bersama mengingat kegiatan pendamping merupakan tanggungjawab bersama di dalam mewujudkan sekolah yang berkualitas. Keempat, kecocokan program mentoring yang dilakukan oleh guru mentor sangat efektif karena hubungan dan kecocokan antara mentor dengan guru yang didampingi saling mendukung. Kelima, menyediakan waktu untuk bimbingan khusus bagi guru yang didampingi baik dilakukan dalam ruang kelas secara sendiri maupun dikumpulkan dalam suatu acara workshop dan pertemuan guru seluruhnya. Keenam, implementasi proses pendampingan, yang akan dianalisis secara terpisah melalui kegiatan observasi. Ketuju, evaluasi dan revisi adalah suatu kegiatan untuk melakukan reviu atau refleksi terhadap seluruh kegiatan yang dilanjutkan dengan perbaikan. Khusus untuk kegiatan ini, seluruh kepala sekolah bersama pengawas sekolah bekerjasama dengan mentor melakukan evaluasi bersama untuk menentukan berbagai kelemahan seperti kesulitan mengatur waktu, membangun kedisiplinan, kegiatan tindak lanjut.

\section{Tahap Pelaksanaan Program Pendampingan}

\section{Observasi}

Observasi dilakukan oleh peneliti mulai pertama pendampingan berlangsung. Observasi ini bertujuan untuk melihat dan merekam fenomena atau kejadian apa adanya yang terjadi pada saat proses pendampingan berlangsung baik yang alamiah maupun yang telah dirancang. Berdasarkan hasil observasi diperoleh hasil sebagai berikut.

Pada saat sosialisasi program pendampingan Ketua Gugus menekankan bahwa guru-guru harus bisa mengubah mindset terlebih dahulu agar dapat mengimplementasikan kurikulum 2013 ini dengan baik, karena salah satu faktor keberhasilan kurikulum 2013 ini adalah perubahan mindset atau pola pikir guru-guru, akan tetapi jika yang terjadi adalah sebaliknya maka guru-guru akan menghadapi kendala dalam mengimplementasikan kurikulum 2013 ini.

Pada kesempatan sosialisasi pendampingan ini Pengawas Gugus III memberikan materi penilaian dalam kurikulum 2013, hal ini dilakukan berdasarkan masukan dari guru-guru mengingat kegiatan pendampingan bertepatan dengan rencana pembagian raport mid semester. Pengawas menyampaikan materi penilaian secara rinci menggunakan media infokus untuk menayangkan bahan ajar power point.

Pada akhir kegiatan sosialisasi pendampingan, Ketua Gugus III mengajukan pertanyaan kepada guru-guru tentang apa yang menjadi kendala mereka dalam implementasi kurikulum 2013. Jawaban yang diberikan oleh guru-guru cukup beragam antara lain adalah; mereka kesulitan dalam pembuatan soal, melakukan penilaian dalam kurikulum 2013 karena belum terbiasa dengan penilaian sikap, pengisian rapot, dan beberapa kendala lainnya. Berdasarkan hasil pertemuan hari pertama pendampingan serta diskusi lebih lanjut dengan pengawas dan Instruktur Nasional, maka Ketua Gugus menyusun ulang jadwal pendampingan yang telah dibuat sebelumnya. Perubahan terjadi pada susunan materi pendampingan yang akan disampaikan, me- 
ngingat salah satu tujuan pendampingan adalah membantu tugas guru dalam implementasi kurikulum 2013 maka pemilihan materi penilaian menjadi pilihan pertama yang akan disampaikan pada kegiatan pendampingan berikutnya.

Pertemuan kedua pendampingan dilaksanakan sesuai dengan kesepakatan awal yaitu pendalaman materi penilaian dalam kurikulum 2013. Masih sama seperti pertemuan pertama, materi penilaian disampaikan oleh Pengawas. Hal menarik yang terjadi dalam kegiatan pendampingan ketika guru-guru menanyakan tentang format rapot mid semester yang akan dibagikan kepada orang tua murid adalah belum adanya kesamaan format baik antar sekolah maupun antar gugus. Hal ini yang membuat para guru menjadi bingung menggunakan format yang mana. Idealnya format rapot adalah seperti yang telah dibuat oleh Kemendikbud yang memuat tiga ranah yaitu sikap, pengetahuan, dan keterampilan. Akan tetapi mengingat sebagian besar guru belum memahami dengan baik bagaimana melakukan penilaian sikap baik K1 sikap spiritual maupun K2 yang terkait dengan sikap sosial, maka pengawas memberikan masukan untuk menggunakan penilaian dari ranah pengetahuan saja yang dilaporkan per mata pelajaran sambil beliau menunjukkan contohnya. Akan tetapi beberapa guru mempertanyakan kenapa mata pelajaran dimunculkan kembali, mengingat saat ini pembelajaran sudah menggunakan tematik. Mereka khawatir akan mengundang reaksi dari wali murid karena pada saat sosialisasi kurikulum 2013 di awal tahun ajaran sudah disampaiakan bahwa rapot tidak akan memasukkan mata pelajaran. Hal ini menjadi kontradiktif dan polemik tersendiri jika tidak dicarikan solusinya. Akhirnya Pengawas memberikan pilihan bahwa apabila sekolah telah mampu membuat penilaian dalam tiga ranah, maka dipersilahkan untuk menyampaikannya dalam format tersebut. Akan tetapi jika sekolah belum mampu membuat laporan dalam tiga ranah, maka Pengawas juga mempersilahkan sekolah menggunakan format penilaian hanya dari satu ranah yaitu pengetahuan saja. Lebih lanjut ditegaskan bahwa nanti di akhir semester sudah harus menggunakan dengan format yang lengkap.

Evaluasi dilakukan antara Pengawas, Ketua Gugus, dan Instruktur Nasional terkait efektifitas kegiatan pendampingan pada setiap akhir pertemuan. Hasil refleksi di pertemuan kedua ini adalah perlu membatasi jumlah guru dan menugaskan guru secara khusus dari masing-masing sekolah dan tidak boleh digantikan oleh guru lain kecuali dengan kondisi tertentu. Guru-guru yang ditugaskan tersebut kemudian ditetapkan sebagai guru model dan dibuatkan Surat Keputusan untuk mempermudah perijinan mereka ketika mengikuti kegiatan pendampingan, tujuan lainnya adalah agar terjadi kontinuitas informasi dari kegiatan pendampingan implementasi kurikulum 2013 di Gugus ke sekolah masing-masing.

Pertemuan ketiga pendampingan dihadiri oleh Pengawas dan Ketua Gugus III, Instruktur Nasional dan guru-guru model yang telah dipilih. Ketua Gugus membuka pertemuan dan menyampaikan rencana kegiatan pendampingan yaitu analisis buku guru dan buku siswa. Selain itu Ketua Gugus juga membacakan nama-nama guru model yang telah dipilih untuk mewakili sekolah masing-masing mengikuti kegiatan pendampingan. Guru model dipilih berdasarkan perwakilan kelas yang sedang 
mengimplementasikan Kurikulum 2013, yaitu setiap sekolah mengirimkan 4 (empat) orang guru yang terdiri dari Guru Kelas 1, 2, 4 dan guru kelas 5. Berhubung jumlah sekolah di Gugus III ada 11 kelas, maka terdapat 44 orang guru model yang secara kontinu mengikuti kegiatan pendampingan dan dikelompokkan berdasarkan kelas yang diampu. Instruktur Nasional yang ditugaskan melakukan pendampingan di Gugus III berjumlah 4 orang, maka setiap kelompok guru model dibimbing oleh seorang Instruktur Nasionalsebagai narasumber.

Selanjutnya Pengawas menyampaikan materi yang terkait dengan analisis buku guru dan siswa yaitu pembuatan RPP. Pengawas menegaskan bahwa dalam membuat RPP terlebih dahulu harus mempersiapkan beberapa dokumen pendukungnya yaitu silabus, buku guru dan buku siswa. Sementara untuk membuat jaring tema dapat melihat dari buku guru dan buku siswa. Pengawas juga menyampaikan bahwa dalam melakukan supervisi penilaian dilakukan dengan melihat dokumen 1 dan 2 Kurikulum 2013, sehingga yang perlu dipersiapkan sekolah antara lain adalah; jadwal, silabus, RPP dan beberapa dokumen pendukung lainnya. Lebih lanjut Pengawas mengatakan bahwa RPP dapat dibuat baik dalam satu hari atau satu pembelajaran maupun satu subtema atau enam pembelajaran.

Evaluasi kegiatan pendampingan kali ini dilakukan oleh Ketua Gugus dan Instruktur Nasional terkait efektifitas pendampingan. Mereka menyimpulkan bahwa pada pertemuan mendatang perlu dilakukan kegiatan praktik secara langsung. Materi pada kegiatan pendampingan berikutnya adalah melakukan pemetaan KI-KD. Ketua Gugus dan Instruktur menyimpulkan bahwa jika kegiatan pendampingan hanya dilakukan dengan metode ceramah maka akan sulit diimplementasikan oleh guru. Oleh karena itu di pertemuan mendatang peserta pelatihan diwajibkan membawa buku guru dan siswa, silabus, dan notebook. Berdasarkan informasi yang diperoleh dari peserta pendampingan adalah tidak semua sekolah memiliki silabus Kurikulum 2013 yang telah dicetak dan dijilid yang bisa mereka gunakan sebagai bahan pendukung, meskipun setiap sekolah telah memiliki softcopy dari semua materi Kurikulum 2013 akan tetapi permasalahan umum yang juga sering terjadi di beberapa daerah lainnya adalah sebagian besar guru belum menguasai aplikasi komputer dengan baik. Sehingga wajar saja silabus yang mereka miliki dalam bentuk softcopy tidak bisa dimanfaatkan oleh guru-guru. Akhirnya disepakati silabus akan dicetak dan digandakan sejumlah sekolah yang dikoordinasi oleh salah satu sekolah untuk digunakan pada pertemuan pendampingan berikutnya. Instruktur juga meminta kepada guru yang telah menguasai aplikasi komputer untuk membawa notebook berikut buku guru dan buku siswa. Sementara bagi guru yang belum menguasai komputer akan diberikan format pemetaan KI-KD yang dicetak dan diperbanyak oleh Instruktur.

Kegiatan pendampingan pada pertemuan kali ini adalah praktik melakukan pemetaan KI-KD. Seperti pada kegiatan pendampingan sebelumnya, Ketua Gugus III membuka acara pendampingan. Kali ini setiap peserta pendampingan telah duduk secara berkelompok dan dipandu oleh satu orang Instruktur di setiap kelompok. Ber- 
dasarkan masukan dari beberapa guru yaitu akan lebih baik jika kegiatan pendampingan langsung memberikan dampak kepada guru saat di sekolah. Contohnya jika akan melakukan pemetaan KI-KD akan semakin bermanfaat jika sesuai dengan Tema Pembelajaran yang sedang berlangsung saat ini. Hal ini sangat dimengerti karena jika melakukan pemetaan KI-KD dengan Tema yang telah disampaikan, maka akan mengulang-ulang saja dan tidak berdampak secara langsung kepada pekerjaan guru saat ini. Oleh karena itu salah satu instruktur menanyakan kepada peserta pendampingan apakah akan meneruskan pada penugasan pemetaan KI-KD berdasarkan tugas yang telah diberikan, atau akan masuk ke Tema yang saat ini berlangsung. Akan tetapi ada pertimbangan lainnya yang tidak bisa diabaikan, yaitu baik buku guru maupun guru siswa Tema ke 3 belum didistribusikan ke sekolah secara merata, tentu saja hal ini akan menghalangi proses pendampingan. Buku guru dan siswa digunakan sebagai bahan acuan melakukan pemetaan KI-KD. Akhirnya diputuskan bahwa untuk melakukan pemetaan kali ini menggunakan buku guru dan siswa dari Tema ke 2 . Selain itu guru juga harus membuka silabus dan salinan Permen No. 67 Tahun 2013 untuk mengkonfirmasi jika ada KD yang tidak tertulis di dalam buku guru. Sebelum kegiatan berlangsung, Instruktur membagikan format pemetaan KI-KD sebanyak 3 lembar bagi guru-guru yang belum menguasai komputer. Pengawas Gugus datang di awal kegiatan dan pada saat kegiatan pendampingan sedang berjalan, beliau memantau secara langsung kegiatan pendampingan kurikulum 2013 dan juga untuk memastikan kegiatan pendampingan berjalan dengan baik sesuai dengan perencanaan.

\section{Angket}

Kegiatan pendampingan ini berlangsung serentak di beberapa wilayah yang telah mengimplementasikan Kurikulum 2013. Pemerintah telah menyusun Pedoman Teknis Pendampingan Implementasi Kurikulum 2013 di Sekolah Dasar lengkap dengan instrumennya. Sebelum kegiatan pendampingan ini dilakukan, orang-orang yang dipilih sebagai pendamping atau narasumber juga telah mengikuti pelatihan. Sehingga diharapkan arah kegiatan pendampingan dapat sesuai dengan tujuannya.

Agar memperoleh informasi tetang kemampuan peserta setelah mengikuti kegiatan pendampingan, maka peneliti menyebarkan angket untuk diisi. Angket Evaluasi Diri tentang Pengetahuan Konsep Kurikulum 2013 dan Implementasinya ini terdiri atas beberapa komponen yaitu; Konsep Kurikulum, Buku Teks dan Buku Pegangan Guru, Penguatan Proses Pembelajaran, Penyusunan RPP, dan Simulasi.

Berdasarkan olah data hasil pengisian angket yang dilakukan dari tujuh komponen penilaian, hasilnya adalah terdapat beberapa komponen di mana guru masih perlu bimbingan lebih sering daripada yang dilakukan sebelumnya. Komponen yang dimaksud adalah Buku Teks dan Buku Pegangan Guru, Penguatan Proses Pembelajaran, dan Penilaian Proses dan Hasil Belajar. Hasil penyebaran angket ini dapat digunakan sebagai acuan dalam menyusun perencanaan pendampingan di kegiatan pendampingan lainnya. 


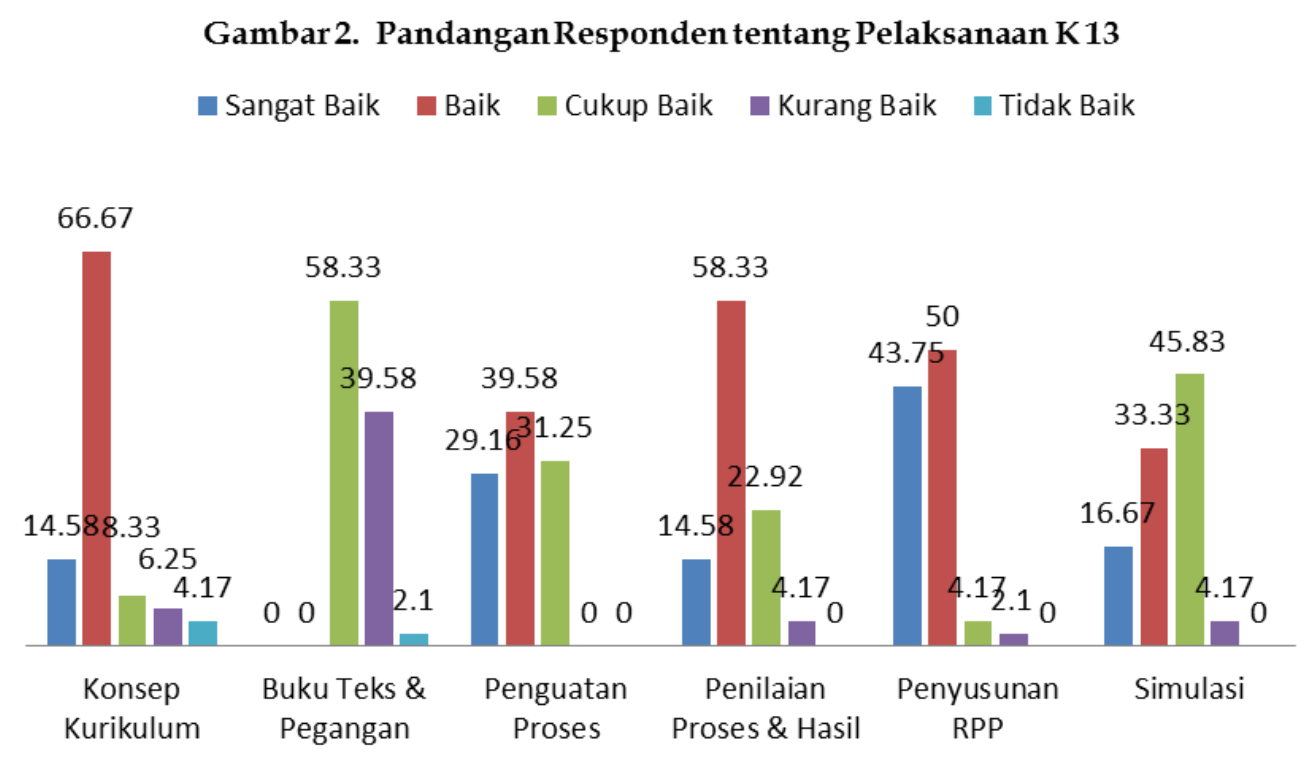

Gambar tersebut memperlihatkan bahwa konsep kurikulum berada pada kategori baik sebanyak $32(67 \%)$ responden. Untuk buku teks dan buku pegangan guru dipandang cukup baik oleh 28 (58\%) responden, sedangkan untuk penguatan proses, nilai yang paling tinggi berada pada kategori baik yang dipilih oleh $19(40 \%)$ responden. Untuk aspek penilaian proses dan hasil penilaian yang paling tinggi berada pada kategori baik yang dipilih oleh 28 (58\%) responden. Pada Aspek penyusunan RPP, nilai tertinggi dipilih oleh 24 (50\%) responden. Adapun aspek simulasi berada pada tingkat cukup baik yang dipilih oleh $22(45 \%)$ responden. Jika diberikan nilai rata-rata dari setiap aspek yang tinggi yakni sebanyak 25 (52,1\%) dan berada pada kategori ba$\mathrm{ik}$, yang artinya bahwa pandangan guru tentang pelaksanaan pendampingan $\mathrm{K} 13$ berada pada kategori baik.

Selain itu, studi dokumentasi dilakukan untuk mengumpulkan data baik yang berupa dokumen atau bahan tertulis, photo, rekaman maupun video. Dalam penelitian ini dokumen yang dikumpulkan sebagai bahan pendukung adalah bahan tertulis yang dibuat oleh Instruktur pada saat pendampingan dan photo-photo selama proses pendampingan berlangsung.

\section{SIMPULAN}

Berdasarkan hasil penelitian yang telah dikemukakan sebelumnya, maka dapat disimpulkan hal-hal sebagai berikut:

1. Tahap perencanaan program pendampingan mencakup mendesain dan merencanakan tujuan program pendampingan, mengidentifikasi potensi guru yang didampingi dan pendampingnya, menfasilitasi orientasi bersama (guru yang diberi pendampingan, pendamping (mentor), dan pengawas), mencocokkan antara pendamping dengan yang didampingi, mempersiapkan peralatan untuk pendampingan, implementasi pendampingan, dan mengevaluasi kemajuan dan mendesain kemba- 
li. Kendala yang dihadapi antara lain adalah sebagian guru masih belum memahami dengan baik proses pembelajaran yang menggunakan pendekatan saintifik, membuat soal ulangan harian, dan rekapitulasi nilai ke dalam rapot.

2. Proses atau pelaksanaan program pendampingan difokuskan pada perubahan mindset, integrasi pendekatan saintifik, dan penilaian otentik. Penilaian otentik lebih banyak difokuskan pada penilaian sikap. Guru dibiasakan untuk mengunakan pembelajaran yang diarahkan untuk mengembangkan aspek kognisi, afeksi, dan psikomotor. Penilaian terhadap pelaksanaan program pendampingan pelaksanaan kurikulum 2013 mencakup buku teks dan buku pegangan guru, penguatan proses pembelajaran, dan penilaian proses dan hasil belajar. Nilai rata-rata dari setiap aspek yang tinggi berada pada kategori baik yang dipilih oleh 25 (52,1\%) yang artinya bahwa pandangan guru tentang pelaksanaan pendampingan $\mathrm{K} 13$ berada pada kategori baik.

\section{CATATAN AKHIR:}

1. Mujiono dan Dimyati, Belajar dan Pembelajaran, Jakarta: Rineka Cipta, 1999, h. 190

2. Jody L. Fitzpatrick, James R. Sanders, dan Blaine R. Worthen, Program Evaluation: Alternative Approaches and Practical Gudelines, New York: Pearson, 2004, h. 5.

3. John M. Owen, Program Evaluation: Forms and Approaches, Crows Nest NSW: Allen \& Unwin, 2006, h. 26.

4. Defense Centers of Excellence, Program Evaluation Guide, Virginia: for Psychological Health and Traumatic Brain Injury, 2012, h. 18.

5. Daniel L. Stufflebeam dan Anthony J. Shikfield, Evaluation, Theory, Models, E Applications, San Fransisco: John Wiley \& Sons, Inc., 2007, h. 58.

6. Alison Greig dkk., Program evaluation of a model to integrate internationally educated health professionals into clinical practice, BMC Medical Education, 2013, 13:14.

7. Valerie Ruhe and J. Donald Boudreau, The 2011 Program Evaluation Standards: a framework for quality in medical education programme evaluations, Journal of Evaluation in Clinical Practice 19, 2013, h. 925-932.

8. Jennifer Browne dkk., A qualitative evaluation of a mentoring program for Aboriginal health workers and allied health professionals, Australian and New Zealand Journal Of Public Health, 2013 vol. 37 no. 5.

9. Olivier Serrat, "Coaching and Mentoring: Knowledge Solutions," ADB Online; http://www.adb.org/documents/information/knowledge-solutions/coaching-and-mentoring.pdf, diakses 3 April 2011.

10. Mary Connor \& Julia Pokora, Coaching and Mentoring at Work: Developing Effective Practice, England: Open University Press, 2007, h. 6.

11. Eric Parsloe, "the Coaching and Mentoring Network: Coach and Mentor Definitions," Couching Network Online; http://www.coachingnetwork.org.uk/resourcecentre/whatarecoachingandmentoring.htm, diakses 20 April 2010.

12. D Clutterbuck \& D Megginson, "Mentoring Executives and Directors," Coaching Network Online; http://www.coachingnetwork.org.uk/resourcecentre/whatarecoachingandmentoring.htm, diakses 24 Maret 2010.

13. National Mentoring Partnership, How to Build a Successful Mentoring Program Using the Elements of the Effective Practice, Washington D.C.: MENTOR/National Mentoring Partnership, 2005, h. 11.

14. Max Lendsberg dalam Ronald F. Pol, "Coaching and the Skill-Will Matrix," Team Factors 
Online;http://www.teamfactors.com/documents/SS29_CoachingandSkill-WillMatrix_ACCDocket.pdf, diakses 24 Maret 2010.

15. Sudarwan Danim, Inovasi Pendidikan, dalam Upaya Meningkatkan Profesionalisme Tenaga Kependidikan, Bandung: Pustaka Setia, 2002, h. 61.

16. Eric Parsloe, The Manager as Coach and Mentor 2ed, Wiltshire, Trowbridge: The Cromwell Press, 1999, h. 8 \& 36.

17. Ibid., h. $8 \& 36$.

18. Dahloan Hembree, www.associatedcontent.com/teachercoachingthebestwaytoretain, htm, diunduh pada tanggal 15 Maret 2010.

19. Nana Syaodih Sukmadinata, Metode Penelitian Pendidikan, Bandung: PT Remaja Rosdakarya, 2010, h. 27.

\section{DAFTAR PUSTAKA}

Browne, Jennifer, dkk., A qualitative evaluation of a mentoring program for Aboriginal health workers and allied health professionals. Australian and New Zealand Journal Of Public Health. 2013, vol. 37 no. 5.

Clutterbuck, D. \& D. Megginson. "Mentoring Executives and Directors". Coaching Network Online; http://www.coachingnetwork.org.uk/resourcecentre/whatarecoachingandmentoring.htm, diakses 24 Maret 2010.

Connor, Mary \& Julia Pokora. Coaching and Mentoring at Work: Developing Effective Practice. England: Open University Press, 2007, h. 6.

Danim, Sudarwan. Inovasi Pendidikan, dalam Upaya Meningkatkan Profesionalisme Tenaga Kependidikan. Bandung: Pustaka Setia, 2002.

Defense Centers of Excellence. Program Evaluation Guide. Virginia: for Psychological Health and Traumatic Brain Injury, 2012, h. 18.

Fitzpatrick, Jody L., James R. Sanders, dan Blaine R. Worthen. Program Evaluation: Alternative Approaches and Practical Gudelines. New York: Pearson, 2004, h. 5.

Greig, Alison, dkk. Program evaluation of a model to integrate internationally educated health professionals into clinical practice. BMC Medical Education, 2013, 13:14.

Hembree, Dahloan. www.associatedcontent.com/ teachercoaching thebest waytoretainhtm Diunduh pada tanggal 15 Maret 2010.

Lendsberg, Max dalam Ronald F. Pol, "Coaching and the Skill-Will Matrix," Team Factors Online;http://www.teamfactors.com/documents/SS29_CoachingandSkill-WillMatrix_ACCDocket.pdf, diakses 24 Maret 2010.

Mujiono dan Dimyati. Belajar dan Pembelajaran. Jakarta: Rineka Cipta, 1999.

National Mentoring Partnership. How to Build a Successful Mentoring Program Using the Elements of the Effective Practice. Washington D.C.: MENTOR/National Mentoring Partnership, 2005, h. 11.

Owen, John M. Program Evaluation: Forms and Approaches. Crows Nest NSW: Allen \& Unwin, 2006, h. 26.

Parsloe, Eric Parsloe. "the Coaching and Mentoring Network: Coach and Mentor Definitions," Couching Network Online; http://www.coachingnetwork.org.uk/resourcecentre/whatarecoachingandmentoring.htm, diakses 20 April 2010.

Parsloe, Eric. The Manager as Coach and Mentor 2ed. Wiltshire, Trowbridge: The Cromwell Press, 1999.

Ruhe, Valerie and J. Donald Boudreau. The 2011 Program Evaluation Standards: a framework for quality in medical education programme evaluations. Journal of Evaluation in Clinical Practice. 19, 2013, h. 925-932. 
Serrat, Olivier. "Coaching and Mentoring: Knowledge Solutions," ADB Online; http://www.adb.org/documents/information/knowledge-solutions/coaching-and-mentoring.pdf, diakses 3 April 2011.

Stufflebeam, Daniel L. dan Anthony J. Shikfield. Evaluation, Theory, Models, E Applications. San Fransisco: John Wiley \& Sons, Inc., 2007, h. 58.

Sukmadinata, Nana Syaodih. Metode Penelitian Pendidikan, Bandung: PT Remaja Rosdakarya, 2010, h. 27. 